\title{
The Development of Teaching Materials for Scientific Report Writing Based on Scientific Learning
}

\author{
Andiopenta Purba \\ Indonesia Language and Literature Study Program \\ Faculty of Education and Teacher Training, Universitas Jambi \\ Jambi, Indonesia \\ penta.andi@gmail.com
}

\begin{abstract}
This study aimed to describe; (1) the product feasibility of scientific report writing instructional materials science, (2) the quality of the layout and appearance of the scientific report writing teaching materials, and (3) the effectiveness of the teaching materials. The applied model of research and development was a model of Borg and Gall. To test the model, this study used effectiveness before-after experiment design and experiment design with posttest-only. The results of the study showed that the feasibility of this model, the content, the presentation, and the accuracy of the use of language use were at very good category. The conclusions of the study were as follows: (1) The model of scientific report writing teaching materials produced in this research and development is feasible to use in the course of writing, so it can be used in order to improve learning outcomes in the course of writing, especially on the topic of writing scientific reports. (2) The model of scientific report writing teaching materials was interesting in terms of the layout and appearance, so that students are motivated to use it and it could increase their creativity in writing skills. (3) The model can be effectively used by faculty and students who take courses in writing skills, in this case on the topic of writing scientific reports.
\end{abstract}

Keywords-Development, Instructional Materials, Writing, Science Report

\section{INTRODUCTION}

At every level of education from elementary, junior high, high school and university, Indonesian language is used as one of the subjects that must be studied. Similarly in the field of non-formal and informal, the government is attempting to do counseling of Indonesian language through language centers and offices in every region in Indonesia. Indonesian society as a direct user of Indonesian language should realize how important the Indonesian language is. This is realized in the view of the Indonesian nation made up of various ethnic backgrounds, cultures, and languages.

To achieve all expectations, the college personnel of education institution prepare prospective Indonesian teachers. Accordingly, all public universities in Indonesia open Indonesian Language and Literature Education Study Program. In order to prepare Indonesian teachers, who of course will be expected to be professional teachers, the curriculum used in the study program is formulated by involving literature based knowledge, language skills, linguistics and the ability to write. One of language skills is writing skill, which is expected to be mastered by students as future teachers. One required writing material is the skill to write a report on observation. This material is aligned with one of the basic competencies to be studied either at the level of junior high school, or vocational. Thus, as student teachers, the candidates must be skilled in writing scientific reports.

In order to equip students on mastery of writing a report on observation, it is necessary to provide effective instructional materials, so that teachers and students do not experience obstacles in the process of understanding the material. In relation to that, this study aimed to develop and produce effective teaching materials in learning writing skill, in this case mainly on the material to write a scientific report. Therefore, the problem in this study focused on product feasibility of the teaching materials for scientific report writing, the quality of the layout and appearance of teaching materials for scientific report writing, and the effectiveness of the teaching materials.

\section{THEORETICAL REVIEW}

\section{A. Essence and Characteristics of Teaching Materials}

Teaching materials are sets of learning materials arranged in a systematic way, showing the figure of the whole of the competencies to be mastered by learners and used in classroom activity [1]. Noting the views of experts, it appears that the teaching materials are tools to achieve the learning objectives that contain content or material taught by teachers and learners to learn. The contents basically contain the knowledge, skills and attitudes that will be absorbed and mastered by learners according to standards of competence and the contents are systematically arranged. Thus, the nature of teaching materials will be regarded in developing the teaching materials in this study.

To prepare teaching materials that fit these characteristics some prominent steps to be done. There are three main steps to 
be done in preparing teaching materials, namely; (1) analyzing the need of teaching materials, (2) drawing up a map of teaching materials, and (3) creating teaching materials [1].

In carrying out a needs analysis of teaching materials, there are three steps that must be taken, i.e. (1) analysis of the curriculum, (2) analysis of learning resources, and (3) analysis of the type of teaching materials. The analysis of the curriculum is the first step of the analysis of the needs of the teaching materials. The steps in analyzing the curriculum are taken with the following procedure [1]. First, we determine the competency standards, the minimum qualification ability of learners (standards of competence) that describe the attitudes, knowledge, and skills that can be achieved at any level/ semester, consisting of a number of basic competences as a reference standard to be achieved and applied nationally. Second, we determine the basic competence, namely a number of capabilities that should possession learners in certain subjects as a reference to develop a competence indicator. Third, indicators of learning outcomes or competencies are formulated, which can be used as a reference in the assessment criteria. Thus, we can know the specific competencies, which will serve as the basis of considerations in determining appropriate teaching materials. Fourth, subject matter, knowledge, skills, or the value are determined so that learners master the competencies that have been set. After analyzing the indicators, we continue the analysis of the subject matter. The subject matter is the main reference in compiling teaching materials. Fifth, the learning experience is determined, which is an activity designed by educators that carried out by the learners to master the competencies that have been determined through the learning activities.

After completion of the first step in developing teaching materials, the curriculum analysis, the second step is the analysis of learning resources. There are three things that must be considered in the analysis of learning resources, among others; availability, suitability and convenience [1]. In more detail, [1] explains that availability criteria refers to the provision of learning resources. The learning resources that are used should be as practical as possible so that it is easy to prepare. Uniformity is whether the intention of learning resources is appropriate to the learning objectives that have been set. The main thing in determination of the criterion is to understand the suitability of learning resources that will have the competencies achieved by learners. Ease/convenience criterion refers to whether it is easy or not to provide and use the learning resources.

The third major step in the development of teaching materials is picking and choosing instructional materials. It aims to meet one of the criteria that teaching materials should be attractive and can help learners to achieve competency. In connection with the selection of teaching materials, there are three principles that can be used as guidelines, among others; the principles of relevance, consistency and adequacy [1]. The principle of relevance means that teaching materials should have relation to the achievement of standards of competence and basic competences. The principle of consistency means that teaching materials have value constancy, so the basic competencies that must be mastered by students and instructional materials provided have alignment. The principle of adequacy applies when selecting teaching materials should be done sufficiently to help students master the basic competencies.

Besides the three things, there are a few more things that are important to consider that can serve as a guide in selecting and determining the teaching materials [1]. Some of them are as follows (1) identification of the aspects contained in the basic competency standards as the reference or references in the selection of instructional materials, whether cognitive, psychomotor or affective; (2) identification to the types of teaching materials, including whether to use the cognitive aspects (facts, concepts, principles or procedures), affective or motor; (3) selection of appropriate teaching material or relevant to the basic competency standards that have been identified. To facilitate the process of selecting and determining the teaching materials, there are also two very important criteria to be considered, namely the general criteria and special criteria. The general criteria are with regard to how to use instructional materials, while the special criteria are related to the usefulness of teaching materials.

The criteria in the selection of learning resources generally include the following four things [1]: (1) economical, which means learning resources are not expensive. With affordable prices, all walks of life will be able to hold the learning resources; (2) practical and simple, which mean learning resources do not need the difficult and rare service or supply; (3) accessible, meaning that sources are close and easy to learn; (4) flexible, meaning learning resources can be used for various purposes of learning, or with other terms 'compatible'. The specific criteria consist of the following (1)learning resources to motivate students to learn; (2) learning resources for teaching purposes. Learning resources should be selected to support teaching and learning activities; (3) learning resources for research, that is the selected learning resources should be observed, analyzed, recorded accurately, and so forth; (4) learning resources to solve the problem, which is the learning resources that are selected should be able to overcome problems faced by learners in learning activities; (5) learning resources for achievement refers to the learning resources which should be able to function as a tool, method or strategy of delivering a message.

\section{B. Writing Scientific Report}

Scientific report writing tends to be also called as writing a report on observation. The observation report is roughly equal to scientific reports, given that the obvious observation is done with scientific procedures. The learning approach starts from the scientific ways to observe, analyze, evaluate, report and communicate. Produced text contains the observation of understanding resulted in the writing of the text that presents information about a matter as it is, which is the result of a systematic observation and analysis. It usually contains facts that can be proven scientifically and general nature. The report 
consists of the opening section in the form of a general definition, part of the contents of a description part, and the final section containing a description of usability.

With regard to the observation report writing, creativity and motivation factors are crucial. The motivation is a series of businesses to provide certain conditions that a person is willing and wants to do something [2]. The motivation of learners focuses on achievement is interpreted as a boost in self-learners to learn, tasks, solve problems and learn specific competencies as well as by the standards of excellence with these characteristics: (1) the success-oriented; (2) the anticipation of failure; (3) innovative; and (4) responsible [3].

Creativity is a general ability to create something new as the ability to provide new ideas is applied in problem solving, or as the ability to see the new relationships between the elements that already existed before [4]. The creative means has the creativity or the ability to create. Based on those opinions, it can be concluded that the form or manifestation of creativity is marked by the results in the form of copyright works [5].

\section{METHOD}

The research method applied in this study was a research and development (research and development). The source of research data was students of second semester of academic year 2015/2016 at Indonesian Language and Literature Education Study Program FKIP Universitas Jambi. The survey respondents are all students of the second semester who took a course to write scientific reports. The type of research data consisted of primary and secondary data. The primary data included data on the analysis of the students' needs of the material of writing scientific reports. The secondary data included the results of the analysis of the syllabus contents and teaching materials that are used bythe lecturer of the course of writing skills. Data were collected by observation, questionnaires, and interviews. This study used Borg and Gall's models with the following: (1) research and information collection, (2) planning, (3) development of an early form of the product, (4) the initial field testing, (5) product revision, (6) the main field testing, (7) revision of product operations, (8) field test operations, (9) revision of the final product, (10) dissemination and implementation [6].

The implementation of product testing begins with all first field test product, the conformity of syllabus content, the content of teaching materials, and the level of syllabus readability and teaching materials. Then, the step was immediately followed by validation 1 by the syllabus and teaching material experts, and ended with the revision phase 1 . After analysis and a revised phase one, direct field testing was conducted to product conformity to syllabus content, the content of teaching materials, and the level of syllabus and teaching material readability. Validation 2 was then conducted by the experts and subsequently operational field test was done to determine the effectiveness of the product through proving the hypothesis by using statistical t-test.
Testing the effectiveness of readability level was done by using the Fray graph through five steps, namely: (1) setting of 100 words from the set of discourse, (2) calculating the number of sentences of 100 words, (3) counting the number of syllables of the entire 100 words, (4) multiplyingg the number of syllables than 100 words with numbers 0.6 , and (5) plotting the number the number of sentences in the second step and the number of syllables in the fourth step to the Fry graph.

In these experiments, teaching materials that have been validated by the experts were tested on the students on a small scale with a technique comparing the results of observations on $\mathrm{O} 1$ with $\mathrm{O} 2$. $\mathrm{O} 1$ was the result of observation of the state of motivation, creativity, and learning outcomes before using teaching materials. $\mathrm{O} 2$ was a state of observation results about motivation, creativity, and learning outcomes after using the product of teaching materials. To determine the effectiveness of the product, if the observation of teaching material from $\mathrm{O} 2$ is higher than the observation of $\mathrm{O} 1$, the product is already effective teaching materials. To measure the state of statistical tests, paired sample t-test was performed.

In addition, re-testing was conducted to determine product quality of the teaching materials and it will be upgraded to the final product. Main product of the teaching materials that have been tested on a small scale re-did the validation experts at the second stage. After that, there was a re-testing of products on a large scale to test the product effectiveness by using the experiment with posttest-only control design.

The design had two groups selected randomly $(\mathrm{R})$. The first group was treated with the experimental group (X) using the product of the teaching materials. The second group was the control group not treated using the product of teaching materials. The observation was then conducted to see the presence or absence of treatment effect and to compare the results of observations between $\mathrm{O} 1$ and $\mathrm{O} 2$. If the observation of $\mathrm{O} 2$ is higher than $\mathrm{O} 1$, the product has good quality.

\section{RESULTS AND DISCUSSION}

\section{A. Product Model}

The product of the teaching materials can be seen in the description below. The title is Technical Report Writing Observations. Material: (1) understanding of scientific reports; (2) rule and characteristics of scientific reports; (3) structure of scientific reports; (4) objective and function of scientific reports; (6) preparation of scientific reports. Duties and Exercise: do the observation of the environment at the campus in Education and Teacher Training Faculty of Universitas Jambi and make reports on the observations that have been implemented. Evaluation: (1). cognitive: (a) describing briefly the following things; (b) understanding of scientific reports; (c) rule and characteristics of scientific reports; (d) structure of scientific reports; (e) objective and function of scientific reports step; (f) preparation of scientific reports. (2) skills: observing the learning process on the basic competence of writing on observation reports in high school. (3) attitude: the 
ability to work together with colleagues and reading list overview of motivation and creativity of students.

\section{B. Validation on Feasibility Aspect}

Validation of the teaching materials to write a report on the observation was conducted by subject matter experts and linguists. The results of the early product validation on the model of the teaching materials is shown in Table 1.

TABLE I. RESULTS OF THE FEASIBILITY ASPECTS of PRODUCT VALIDATION

\begin{tabular}{|c|c|c|c|c|}
\hline $\begin{array}{c}\text { Aspects } \\
\text { Validation }\end{array}$ & $\begin{array}{c}\text { Expert } \\
\text { Matter }\end{array}$ & $\begin{array}{c}\text { Language } \\
\text { Category }\end{array}$ & Mean & Category \\
\hline $\begin{array}{c}\text { Eligibility of } \\
\text { Contents }\end{array}$ & 4.25 & 4.13 & 4.19 & Very Good \\
\hline $\begin{array}{c}\text { Compliance of } \\
\text { Presentation }\end{array}$ & 4.02 & 4.18 & 4.10 & Very Good \\
\hline $\begin{array}{c}\text { Accuracy of } \\
\text { Language }\end{array}$ & 4.08 & 4.11 & 4.09 & Very Good \\
\hline Average & $\mathbf{4 . 1 1}$ & $\mathbf{4 . 1 4}$ & $\mathbf{4 . 1 2}$ & Very Good \\
\hline
\end{tabular}

\section{Validation on Appearance and Layout Aspects}

The validation of the teaching materials was conducted by subject matter experts. The results of the early product validation on the model of the teaching materials is shown in Table II.

TABLE II. RESULTS OF VALIDATION ON APPEARANCE AND LAYOUT ASPECTS

\begin{tabular}{|l|c|c|c|c|}
\hline $\begin{array}{c}\text { Validation } \\
\text { Aspects }\end{array}$ & $\begin{array}{c}\text { Validation } \\
\text { Matter }\end{array}$ & $\begin{array}{c}\text { Expert } \\
\text { Linguist }\end{array}$ & Mean & Category \\
\hline $\begin{array}{l}\text { 1. Cover } \\
\text { Design }\end{array}$ & 3.98 & 4.06 & 4.02 & Very Good \\
\hline $\begin{array}{l}\text { 2. Design } \\
\text { Content }\end{array}$ & 4.03 & 4.12 & 4.07 & Very Good \\
\hline $\begin{array}{l}\text { 3. Design } \\
\text { and } \\
\text { Printed } \\
\text { Letter }\end{array}$ & 4.13 & 4.20 & 4.16 & Very Good \\
\hline $\begin{array}{l}4 . \\
\text { Design } \\
\text { Figure }\end{array}$ & 4.26 & 4.29 & 4.27 & Very Good \\
\hline $\begin{array}{l}\text { 5. Quality } \\
\text { bindings }\end{array}$ & 4.31 & 4.42 & 4.36 & Very Good \\
\hline Mean & 4.14 & 4.21 & 4.17 & Very Good \\
\hline
\end{tabular}

\section{Limited Scale Testing Results}

Testing of the report scientific writing teaching materials on the observation was conducted on a limited group of 10 students. Assessment tests were carried out before and after using the teaching materials. The results be seen in Table III.

TABLE III. EFFECTIVENESS OF THE PRODUCT USED BEFORE AND AFTER

\begin{tabular}{|c|c|c|}
\hline $\begin{array}{c}\text { Aspects Effectiveness } \\
\text { Instructional }\end{array}$ & Before Used & After Used \\
\hline Students' motivation to learn & $60 \%$ & $85 \%$ \\
\hline Creativity of students & $66 \%$ & $89 \%$ \\
\hline Results of student learning & $68 \%$ & $90 \%$ \\
\hline Mean & $64.66 \%$ & $88 \%$ \\
\hline
\end{tabular}

From the test results on a limited scale in Table III, that effect of the teaching materials on the results of observation in terms of students' learning motivation can be increased by $25 \%$. The creativity of student can be increased by $23 \%$, and student learning outcomes can be increased by $22 \%$.

Table IV shows the effectiveness of the teaching materials performed on testing in a limited scale through t-test. The obtained value for motivation was 7.135, and the t-table with a level of significance of 0.05 was 2.306 (7.135> 2.306). Likewise, the creativity of students was $7.126>2.306$ and learning outcome was $9.368>2.306$. The effectiveness of the teaching materials on motivation, creativity, and the results of student learning before the use of the product was significantly different from after the use of the product.

TABLE IV. TEST RESULTS ON MOTIVATION, CREATIVITY, AND STUDENT LEARNING OUTCOMES IN LIMITED SCALE TESTING

\begin{tabular}{|c|c|c|c|c|}
\hline Observation Aspects & Mean & $\begin{array}{c}\mathrm{t}- \\
\text { Observa- } \\
\text { tion }\end{array}$ & t-Table & Description \\
\hline $\begin{array}{ll}\text { Effectiveness } & \text { of } \\
\text { Teaching Materials } & \text { on } \\
\text { Motivation } & \end{array}$ & & & & \\
\hline Before & 3.78 & & & \\
\hline After & 4.02 & 7.135 & 2.306 & Significant \\
\hline $\begin{array}{ll}\text { Effectiveness of } \\
\text { Teaching Materials on } \\
\text { Creativity }\end{array}$ & & & & \\
\hline Before & 3.80 & & & \\
\hline After & 4.12 & 7.126 & 2.306 & Significant \\
\hline $\begin{array}{lr}\text { Effectiveness } & \text { of } \\
\text { Subjects' Learning } \\
\text { Outcome }\end{array}$ & & & & \\
\hline Pra-test & 65.50 & & & \\
\hline Post-test & 80,45 & 9.368 & 2.306 & Significant \\
\hline
\end{tabular}

\section{E. Wide Testing Results}

Effectiveness testing of the teaching materials was widely done to ensure final product quality conducted on control group and experimental group. The results be seen in Table V.

TABLE V. RESULTS OF COMPARATIVE EFFECTIVENESS OF THE TEACHING MATERIALS BETWEEN CONTROL AND EXPERIMENTAL GROUPS

\begin{tabular}{|c|c|c|}
\hline $\begin{array}{c}\text { Effectiveness of The } \\
\text { Teaching Materials }\end{array}$ & Before Used & After Used \\
\hline Students' learning motivatior & 3.95 & 4.26 \\
\hline Students' Creativity & 3.87 & 4.56 \\
\hline Students' Learning Outcomes & 68.65 & 87.95 \\
\hline
\end{tabular}

From the test results on the wide scale, the effect of the teaching materials from the results of observation in terms of students' learning motivation can be increased by 0.31 . The creativity of student can be increased by 0.69 , and students' learning outcomes can be increased by 19.30 . 
TABLE VI. TEST RESULTS OF EFFECTIVENESS OF DIFFERENT TEACHING MATERIALS IN WRITING REPORTS

\begin{tabular}{|c|c|c|c|c|c|c|}
\hline & $\begin{array}{c}\text { Learn- } \\
\text { ing } \\
\text { Motivati- } \\
\text { on }\end{array}$ & $\begin{array}{c}\text { Learning } \\
\text { Creativity }\end{array}$ & & $\begin{array}{c}\text { Learning } \\
\text { Outcomes }\end{array}$ & \\
\hline & $\boldsymbol{X} \mathbf{1}$ & $\boldsymbol{X} \mathbf{2}$ & $\boldsymbol{X} \boldsymbol{1}$ & $\boldsymbol{X} \mathbf{2}$ & $\boldsymbol{X} \mathbf{1}$ & $\boldsymbol{X} \mathbf{2}$ \\
\hline Mean & 3.95 & 4.26 & 3.87 & 4.56 & 68.65 & $\begin{array}{c}87.9 \\
5\end{array}$ \\
\hline $\begin{array}{c}\text { t- } \\
\text { vation- }\end{array}$ & 52.43 & & 89.99 & & 79.74 & \\
\hline $\begin{array}{c}\text { t- } \\
\text { Table }\end{array}$ & 2.021 & & 2.021 & & 2.021 & \\
\hline
\end{tabular}

Table VI shows the effectiveness of the teaching materials for writing scientific reports on the observation after conducting broad-scale testing with different test statistic of ttest. The observed value for motivation was 52.43 , and a ttable with a level of significance of 0.05 was 2.021 , so 52.43 $>2,021$. Similarly, the creativity of the students was $89.99>$ 2.021 and learning outcome was $79.74>2.021$. Thus the working hypothesis is accepted, so there was significant difference in motivation, creativity, and learning outcomes between students who used the teaching materials for writing scientific reports those who did not use the teaching materials.

\section{F. Discussion}

In the implementation of research and development to produce teaching materials for writing scientific reports based on observation, the development of research procedures was depicted on the methodology of the study. This study is in line with the implementation of the development through phaseby-phase and aimed to produce teaching materials for writing scientific reports.

The benefits of this product are as follows. These teaching materials were designed based on the analysis of the needs of students. The teaching materials were drawn up by the steps of development were are designed with the appealing appearance. Furthermore, the teaching materials have described the purpose of learning from the knowledge, attitudes, and skills, consisting of materials, exercises and assignments, as well as evaluation. This product can also be used independently. However, there are still weaknesses of the teaching materials written. That is because of time constraints and the implementation of development research. Some of these shortcomings are that the product has not yet outlined the steps the learning process and has not described the utilization of instructional media.

Based on the results of this study, the teaching materials for writing scientific reports is feasible to use in the course of writing. It is because the study has been in accordance with the steps that have been developed by Borg and Gall model [6]. The teaching materials can also increase motivation and creativity in writing. It is because the study has been in accordance with the criteria in the selection of learning resources [1].

\section{CONCLUSIONS}

The conclusions of this study are as follows: (1) The teaching materials for writing scientific reports produced in this research and development is feasible to use in the course of writing, so it can be used in order to improve learning outcomes in the course of writing, especially on the topic of writing scientific reports; (2) The teaching materials are interesting in terms of the layout and appearance, so students are motivated to use them and increase their creativity in writing skills; (3) The teaching materials are effective teaching materials used by faculty and students who take courses in writing skills, in this case on a topic to write a scientific report.

\section{REFERENCES}

[1] A. Prastowo, Free Creative Creating Innovative Teaching Material: Learning Method Creates Interesting and Exciting, Yogyakarta: Diva Press, 2014.

[2] Sardiman, Interaction and Motivation to Learning, Jakarta: PT. Radjagrafindo, 2010.

[3] E. P. Widoyoko, Evaluation of Learning Program, Yogyakarta: Pustaka Pelajar, 2012.

[4] Munandar, Kreativitas dan Keterbakatan: Strategi Menujudkan Potensi Kreatif dan Bakat, Jakarta: PT. Gramedia Pustaka Utama, 2002.

[5] Sukirno, Belajar Cepat Menulis Kreatif Berbasis Kuantum, Yogyakarta: Pustaka Pelajar, 2013.

[6] W. R. Borg and M. D. Gall, Educational Research. An Introduction (5th ed), New York: Longman, 1989. 